\title{
Effects of Amazonian Dark Earths on growth and leaf nutrient balance of tropical tree seedlings
}

\author{
Estela Quintero-Vallejo • Marielos Peña-Claros • \\ Frans Bongers • Marisol Toledo • Lourens Poorter
}

Received: 26 December 2014 / Accepted: 7 June 2015 / Published online: 10 July 2015

(C) The Author(s) 2015. This article is published with open access at Springerlink.com

\begin{abstract}
Background and aims Amazonian Dark Earths (ADE) are ancient anthropogenic soils distributed in the Amazon basin. They are characterized by high nutrients such as phosphorus, calcium, potassium and nitrogen. We studied the effect of ADE on growth, morphology and physiology of 17 tree species from a Bolivian tropical moist forest.

Methods We conducted a greenhouse experiment where seedlings were grown for 2-4 months on ADE and nonADE. We evaluated soil nutrient concentrations, seedling growth, leaf and root functional traits, and leaf nutrient concentrations.

Results Soil type affected 10 out of 24 evaluated seedling traits. Seedlings did not invest more in roots in non-
\end{abstract}

Responsible Editor: Hans Lambers.

Electronic supplementary material The online version of this article (doi:10.1007/s11104-015-2558-6) contains supplementary material, which is available to authorized users.

E. Quintero-Vallejo $(\bowtie) \cdot$ M. Peña-Claros $\cdot$ F. Bongers $\cdot$

L. Poorter

Forest Ecology and Forest Management Group, Wageningen

University and Research Centre, P.O. Box 47, 6700

AA Wageningen, The Netherlands

e-mail: estela.quinterovallejo@wur.nl

E. Quintero-Vallejo $\cdot$ M. Peña-Claros $\cdot$ M. Toledo Instituto Boliviano de Investigación Forestal (IBIF), P. O. Box 6204, Santa Cruz de la Sierra, Bolivia

M. Toledo

Facultad de Ciencias Agrícolas, Universidad Autónoma Gabriel René Moreno, Km 9 Carretera al Norte, Santa Cruz de la Sierra, Bolivia
ADE, but they invested in leaves and leaf area in ADE, although this did not lead to faster growth rate. Species responded differently to soil Ca increment; some species seemed to suffer from Ca toxicity as indicated by low survival, others from nutrient imbalance, whereas other species increased their leaf calcium, phosphorus and nitrogen concentration in ADE. Only for this latter group of nutrient accumulators, there was a positive interspecific relationship between leaf $\mathrm{Ca}$ and seedling growth rates.

Conclusions ADE did not lead to increased seedling growth. The ability of plants to colonize patches of ADE might depend on plant responses to increased soil $\mathrm{Ca}$ and their capacity to regulate internal tissue calcium to balance nutrition.

Keywords Amazonian Dark Earths · Bolivia · Calcium coping strategies $\cdot$ Nutrient imbalance $\cdot$ Relative Growth Rate

\section{Introduction}

Nutrient availability in tropical soils is the result of complex biogeochemical processes that generate high spatial heterogeneity (Townsend et al. 2008). This heterogeneity is important, since it can determine tree species distribution at different spatial scales (John et al. 2007). However, the exact mechanisms that drive the underlying patterns of plant distribution are still far from being fully understood. This lack of explanation is partly because plants respond differently to a multitude of soil- 
related factors, such as water availability (BrenesArguedas et al. 2013) and nutrients (Ordoñez et al. 2009). Among nutrients, nitrogen (N) and phosphorus (P) are the major limiting elements for primary productivity of forests (Vitousek et al. 2010). Nevertheless, recent fertilization studies have found that potassium $(\mathrm{K})$ and calcium $(\mathrm{Ca})$ influence plant growth in tropical forest, in similar ways as N and P (Baribault et al. 2012; Wright et al. 2011).

Plants respond to soil nutrient availability through a suite of traits, by adjusting their allocation patterns, morphology, tissue chemistry and physiology. With an increase in soil nutrient availability, plants shift biomass allocation to aerial structures, such as leaves, instead of underground structures such as roots (Poorter et al. 2012). This is usually accompanied by changes in other plant traits such as an increase in specific leaf area (SLA), $\mathrm{N}$ and $\mathrm{P}$ concentration in leaves, and growth (Ordoñez et al. 2010; Ordoñez et al. 2009). On the other hand, in soils with low-nutrient availability, plants grow slowly, have a smaller leaf area and allocate more biomass to roots, thus enhancing nutrient uptake (Baraloto et al. 2006). Plant tissue chemistry changes with soil fertility, which is usually reflected in the nutrient concentration of leaves, particularly leaf $\mathrm{N}$ and $\mathrm{P}$ and their ratio (Ågren 2004; Townsend et al. 2007). Apart from soil fertility, foliar nutrient concentrations are shaped by a number of other factors, such as soil $\mathrm{pH}$ (Lambers et al. 2008; Viani et al. 2014), plant demands for elements such as calcium $(\mathrm{Ca})$ to increase tissue toughness (Baribault et al. 2012), negative interactions between tissue $\mathrm{P}$ and aluminum (Al) when plants tend to accumulate Al (Metali et al. 2015), species phylogeny (Watanabe et al. 2007), and symbiotic relationships between plants and microorganisms (Nasto et al. 2014). As a result, plant nutrient concentrations and their stoichiometry can be uncoupled from those in the soil.

Soil $\mathrm{pH}$ is an important factor in plant nutrition; it may limit the availability of a range of elements that are important for plant growth (e.g., iron [Fe] and zinc $[\mathrm{Zn}]$ ), and may raise the availability of other elements, such as Al, that could cause plant mortality (Lambers et al. 2008). For example, in soils with a low $\mathrm{pH}(<5.8)$, increases in $\mathrm{Al}$ and $\mathrm{Fe}$ availability lead to decreases in $\mathrm{P}$ availability by reaction of $\mathrm{Al}$ and $\mathrm{Fe}$ with inorganic $\mathrm{P}$ to form plant unavailable insoluble compounds (McDowell et al. 2003). Furthermore, an increase in soil $\mathrm{Al}$ affects root elongation or plant uptake of other elements such as $\mathrm{Ca}$ and magnesium $(\mathrm{Mg})$, causing reduced development of roots, depression of growth and potentially plant death (George et al. 2012). On the other hand, in soils with high $\mathrm{pH}(\sim 7.4)$ such as calcareous soils, increased concentrations of available $\mathrm{Ca}$ can react with inorganic $\mathrm{P}$ and form calcium phosphate, which makes $\mathrm{P}$ unavailable for most plants (Tyler 1996). Besides, in soils with high $\mathrm{pH}$, some elements such as $\mathrm{Fe}, \mathrm{Mn}, \mathrm{Zn}$ and $\mathrm{Cu}$ form oxide-bound complexes and become unavailable, thus limiting plant growth (Lee 1998).

In general, soils in the tropics have low $\mathrm{pH}$ (Von Uexküll and Mutert 1995) and a low availability of a range of nutrients. However, Neotropical soils can also be diverse in their chemical properties as a result of different geological processes. In particular, the Amazon basin has experienced a long and dynamic geological history (Hoorn et al 2010). In combination with different biogeochemical processes (Quesada et al. 2010) this has led to a wide variation in soil characteristics and different availability of nutrients such P, Ca, $\mathrm{Mg}$, and $\mathrm{K}$. Despite the fact that most of the Amazon basin has a low soil fertility, there are patches of Amazonian Dark Earths (ADE) with high soil fertility that are the product of past human inhabitation of the region since pre-Columbian times (Glaser and Birk 2012).

Amazonian Dark Earths are characterized by a thick dark or gray top layer (up to $1.5 \mathrm{~m}$ deep) with presence of ceramics that indicates past indigenous settlements (Sombroek 1966; Woods and Glaser 2004). ADE have a black color due to high concentrations of organic matter and black carbon, they have high $\mathrm{P}$ and $\mathrm{Ca}$, and higher $\mathrm{pH}$ than the natural soils commonly found in the Amazon, such as Ultisols and Oxisols (Falcão et al. 2009; Glaser and Birk 2012; Sombroek 1966). ADE seem to be the product of additions of charcoal and organic waste which change soil physic-chemical characteristics (Schmidt et al. 2014). For example, charcoal addition leads to a more stable organic matter content, and a high soil nutrient retention capacity (Glaser et al. 2002), while the addition of organic waste leads to high concentrations of P, N, and Ca (Glaser 2007). Compared with natural Central Amazonian soils, ADE are more fertile because of the combination of high $\mathrm{pH}$ and $\mathrm{Ca}$ and $\mathrm{P}$ - concentrations. For this reason, $\mathrm{ADE}$ are often used by local farmers to grow crops faster for longer periods of time compared with slash and burn agriculture practiced on regular soils in the Amazon (German 
2003). Similarly, a forest growing on ADE has increased gross primary productivity, net primary productivity, and higher rates of fine root production compared with a forest growing on non-ADE (Doughty et al. 2014).

By stimulating productivity, the high fertility of ADE could promote changes in plant traits associated with acquisition strategies such as higher relative growth rate, higher leaf biomass and higher nutrient concentrations in the leaves. Evaluating changes in plant traits associated with ADE provides a unique opportunity to understand tree responses to soil fertility as a consequence of past human inhabitation and soil modification. It could also help to understand how soil fertility influences species composition in habitats that do not vary in climatic conditions and water availability.

Here we present results of a greenhouse experiment, in which seedlings of 17 tropical tree species were grown on ADE and non-ADE. We examined how soil fertility of ADE affected seedling growth, biomass allocation, and morphological and chemical traits of tropical tree species. We hypothesized that plants growing on ADE would have higher growth rates compared with plants growing on non-ADE. We also hypothesized that the higher growth rates of seedlings on ADE would be associated with increases in biomass allocation to stem and leaves, leaf N, Ca and P concentrations, specific leaf area and leaf area ratio, which are traits that enhance light capture and carbon gain. We also predict that seedlings growing on less fertile non-ADE will have higher biomass allocation to (secondary) roots and produce roots with higher specific root length to enhance nutrient uptake.

\section{Methods}

Species and collection site Seventeen tree species were selected for the study based on seed availability. Hereafter species will be referred by the genus name (Table 1). Most of the seeds were collected from a semievergreen forest (La Chonta forest concession) located in the province of Guarayos, Bolivia $\left(15^{\circ} 47^{\prime} \mathrm{S}, 62^{\circ} 55^{\prime}\right.$ W) in July and August of 2012. The site has a mean annual temperature of $24.3^{\circ} \mathrm{C}$ and mean annual rainfall of $1580 \mathrm{~mm}$ (data from 2000 to 2006 from La Chonta) with a dry season ( $<100 \mathrm{~mm} / \mathrm{month})$ from May through September (Peña-Claros et al. 2012). Soils at La Chonta are a mosaic of poor soils from the Brazilian Precambrian Shield (Navarro and Maldonado 2002) and more fertile soils that are the product of sedimentation and erosion originated from the uplift of central Andes (Latrubesse et al. 2010). A previous study
Table 1 Scientific names and families of tree species used for this study

Information on presence of nodules in roots, as reported in the literature, is shown with the number corresponding to its reference. Information on observed nodules in roots of seedlings used in this experiment is shown. $(+)$ represents nodules present, and (-) represents nodules absent

${ }^{1}$ (de Faria and de Lima 1998)

${ }^{2}$ (Barberi et al. 1998)

${ }^{3}$ (Sprent and Parsons 2000)

${ }^{4}$ (Frioni et al. 2001)

${ }^{5}$ (Lima et al. 2006)

\begin{tabular}{llll}
\hline Scientific Name & Family & \multicolumn{2}{c}{ Nodules present in roots } \\
\cline { 2 - 4 } & & Reported & Observed \\
\hline Albizia niopiodes (Spruce ex Benth.) Burkart & Fabaceae & $+{ }^{1}$ & + \\
Anadenanthera colubrina (Vell.) Brenan & Fabaceae & $+{ }^{3}$ & - \\
Enterolobium contortisiliquum (Vell.) Morong & Fabaceae & $+{ }^{2,3,4}$ & - \\
Erythrina crista-galli L. & Fabaceae & $+{ }^{4}$ & + \\
Hymenaea courbaril L. & Fabaceae & $-{ }^{2,5}$ & - \\
Machaerium villosum Vogel & Fabaceae & $+{ }^{2}$ & - \\
Ormosia nobilis Tul & Fabaceae & $+{ }^{1}$ & \\
Poeppigia procera C. Presl & Fabaceae & \\
Samanea tubulosa (Benth.) Barneby \& J.W. Grimes & Fabaceae & \\
Schizolobium parahyba (Vell.)S.F. Blake & Fabaceae & \\
Terminalia oblonga (Ruiz \& Pav.) Steud. & Combretaceae & \\
Cariniana ianeirensis R. Knuth & Lecythidaceae & \\
Chorisia speciosa A. St.-Hil. & Malvaceae & \\
Guazuma ulmifolia Lam. & Malvaceae \\
Cedrela fissilis Vell. & Meliaceae \\
Swietenia macrophylla King & Meliaceae & \\
Sapindus saponaria L. & Sapindaceae & \\
\hline
\end{tabular}


showed that La Chonta also has Amazonian Dark Earth (ADE), which are anthropogenic soils indicating inhabitation of this forest in the past (Paz-Rivera and Putz 2009).

Study site The experiment was carried out in a shade house at the Agronomy Faculty of the Universidad Autónoma Gabriel Rene Moreno in Santa Cruz de la Sierra, Bolivia $\left(16^{\circ} 30^{\prime} \mathrm{S}, 63^{\circ} 10^{\prime} \mathrm{W}\right)$. The climate in this city is warm, with an average temperature of $24.2 \pm$ $0.8^{\circ} \mathrm{C}$, and mean annual rainfall of $1308 \pm 391 \mathrm{~mm}$ (Data from National Institute of Meteorology, Bolivia; 1949-2013). The $6 \times 3 \mathrm{~m}$ shade-house was built and covered with black mesh $(2 \times 1.5 \mathrm{~mm})$ to give an irradiance of about $10 \%$ of full sunlight (around 400 lux). This level of light is similar or even higher than the light encountered in the understory of a tropical rain forest ( $\sim 1-2 \%$ ), where seedlings of most tropical tree species grow well (Poorter 1999).

Soils and shade-house experiment The soil used for testing germination and plant growth was collected at La Chonta, where we previously identified a site with dark earth and the presence of pottery shards, hereafter $\mathrm{ADE}$, and a site at least $500 \mathrm{~m}$ away with more clear soils, hereafter non-ADE. Soils were mixed with river sand at a ratio of $4: 1(\mathrm{w} / \mathrm{w})$, to allow adequate drainage and to facilitate harvesting of the whole root system, including fine roots. Although the use of sand could dilute the effect of soil nutrients, we considered that this dilution might not affect our experiment because the differences between ADE and non-ADE were retained for most of the soil variables except total N (Table 2). Chemical and physical characteristics of the original soils and of the mixture with sand were assessed in the Centro de Investigación Agrícola Tropical (CIAT), in Santa Cruz, Bolivia (protocols for chemical and physical properties can be seen in Online Resource 2). The main differences in soil variables between ADE and non-ADE sand mixes were found for $\mathrm{Ca}$ concentration, $\mathrm{P}$ concentration, total exchangeable base and cation exchange capacity (ratios between ADE and non-ADE were $>2$ in all cases); soil $\mathrm{pH}$ was slightly alkaline $(>7)$ in both soils (ADE: 7.8; non-ADE:7.6) (Online Resource 1).

From April to September of 2013 seeds were germinated in trays of $25 \times 30 \mathrm{~cm}$ filled with either ADE or non-ADE sand mixes. When seedlings produced their first leaves, eight seedlings per species per soil type were harvested and 12 seedlings per species per soil type were transplanted to pots of $650 \mathrm{ml}(9.2 \mathrm{~cm}$ diameter $\times 15 \mathrm{~cm}$ height). The transplanted seedlings were placed in a completely randomized design in the shade-house and were re-randomized every 3 weeks to ensure that all seedlings were growing under similar light and temperature conditions. Plants were watered daily or every other day depending on the weather, since the shade house allowed rain water to pass through.
Table 2 Soil characteristic of Amazonian Dark Earths and nonAmazonian Dark Earth collected in La Chonta forest concession, before and after mixing them with river sand

Ratios between values on $\mathrm{ADE}$ and non-ADE after the mixing with river sand are presented. Phosphorus reported on this table was obtained using Olsen Method for soil $\mathrm{P}$ extraction (See, Online Resource 1)

\begin{tabular}{llllll}
\hline & ADE & non-ADE & $\begin{array}{l}\text { ADE/River } \\
\text { sand }\end{array}$ & $\begin{array}{l}\text { non-ADE/ } \\
\text { River sand }\end{array}$ & $\begin{array}{l}\text { Ratio variables on } \\
\text { ADE:non-ADE }\end{array}$ \\
\hline $\mathrm{pH}$ & 7.4 & 7 & 7.8 & 7.6 & 1 \\
Electric conductivity $(\mu \mathrm{S} / \mathrm{cm})$ & 226 & 108 & 218 & 149 & 1.5 \\
$\mathrm{Ca}(\mathrm{cmol} / \mathrm{kg})$ & 12.2 & 4.8 & 10 & 4.2 & 2.4 \\
$\mathrm{Mg}(\mathrm{cmol} / \mathrm{kg})$ & 1.3 & 1 & 1.1 & 0.8 & 1.4 \\
$\mathrm{Na}(\mathrm{cmol} / \mathrm{kg})$ & 0.11 & 0.04 & 0.09 & 0.05 & 1.8 \\
$\mathrm{~K}(\mathrm{cmol} / \mathrm{kg})$ & 0.38 & 0.26 & 0.28 & 0.2 & 1.4 \\
Olsen-P (mg/kg) & 36 & 12 & 35 & 11 & 3.2 \\
Total N (\%) & 0.31 & 0.16 & 0.18 & 0.11 & 1.6 \\
Total Exchangable bases & 14 & 6.1 & 11.5 & 5.3 & 2.2 \\
Cation Exchange Capacity & 14 & 6.1 & 11.5 & 5.3 & 2.2 \\
Base Saturation (\%) & 100 & 100 & 100 & 100 & 1 \\
Organic Mater (\%) & 3.3 & 2.7 & 2.9 & 2.2 & 1.3 \\
Sand (\%) & 49 & 57 & 68 & 73 & 0.9 \\
Silt (\%) & 39 & 36 & 25 & 20 & 1.2 \\
Clay (\%) & 12 & 7 & 7 & 7 & 1 \\
\hline
\end{tabular}


Once seedlings were established, at around half of the growing period, the number of leaves on each seedling was counted and the newest fully developed leaves were tagged with colored threads. At the time of harvesting we counted the number of newly produced leaves.

A second harvest was done between 2 and 4 months after transplanting, depending on the species. Differences in length of the growing period were due to differences in germination time, and lack of seed availability of some species at the time we started the experiment. At each harvest, we determined the fresh mass of roots, stems, and leaves; leaves were sectioned into the leaf lamina and the petiole, or rachis for compound leaves, and sections were weighed separately. Laminae were scanned with a desktop scanner (Cannon LIDE 20, Canon, USA) and leaf area was determined using the software program ImageJ (Rasband 2008). Leaf resistance to mechanical damage was measured for nine of thirteen species using force to punch. Force to punch was determined on one or two of the newest expanded leaves using a field penetrometer, which consisted of a flat-end nail of $3.2 \mathrm{~mm}$ in diameter; the nail was attached to the inner part of a syringe and a water basin on top. A leaf was placed between two acrylic plates both having a $6 \mathrm{~mm}$ diameter hole. The holes were located in the same position so that the nail could cross the leaf between the two plates similar to Aranwela et al. (1999). Force to punch the leaf was determined by the weight (converted to Newton) of the water added to the basin that was necessary to penetrate the leaf, divided by the circumference of the punch nail.

Root length (RL) was determined following Newman (1966). Roots were placed in a tray filled with water. The tray was covered by a transparent sheet marked with $1 \times 1 \mathrm{~cm}$ square grid and the number of intersections between roots and the gridlines were counted horizontally and vertically. Thereafter, total root length was determined as $\mathrm{R}=\pi \mathrm{NA} / 2 \mathrm{H}$, where $\mathrm{R}$ is the total length of the root $(\mathrm{cm}), \mathrm{N}$ is the number of intersections between the root and the gridlines, $\mathrm{A}$ is the area of the rectangle $\left(\mathrm{cm}^{2}\right)$ and $\mathrm{H}$ is the total length of the straight lines of the grid (cm) (Newman 1966). Root morphology was described by the presence/absence of tap roots and by the number of secondary roots. When tap roots were present both the diameter of the base (close to the transition to stem) and the diameter of the tip were measured. The diameter of three secondary roots was measured with a digital caliper.
We measured stem length from the base to the apical bud, and top and base stem diameter. Stem volume was calculated using the formula for a section of a cone. Lamina and petioles, roots and stems were stored in separate paper bags, oven-dried at $70{ }^{\circ} \mathrm{C}$ for $72 \mathrm{~h}$, and weighted again to determine dry weight of plant sections. Using the dry weights we calculated root mass fraction (RMF, $\mathrm{g} \mathrm{g}^{-1}$ ), leaf mass fraction (LMF, $\mathrm{g} \mathrm{g}^{-1}$ ) and stem mass fraction (SMF, $\mathrm{g} \mathrm{g}^{-1}$ ) as the weight of each plant part over the total seedling dry mass. We also calculated stem, root and leaf dry matter content (SDMC, RDMC, LDMC, respectively, in $\mathrm{g} \mathrm{g}^{-1}$ ) as the dry mass over the fresh mass of that section. Specific leaf area (SLA, $\mathrm{m}^{2} \mathrm{Kg}^{-1}$ ) was calculated as the ratio between leaf area and leaf dry mass, leaf area ratio (LAR, $\mathrm{m}^{2} \mathrm{Kg}^{-1}$ ) as the total leaf area over total seedling dry mass, specific root length (SRL, $\mathrm{m} \mathrm{Kg}^{-1}$ ) as root length over dry root mass and root length per plant mass (RLPM m Kg${ }^{-1}$ ) as the root length over total seedling dry mass.

These traits determine important functional characteristics for the plants. Biomass fractions of seedling sections describe how plants allocate biomass to light intercepting tissue in the case of leaves, or nutrient capturing tissue in the case of roots. Stem, root and leaf dry matter content, and force to punch indicate tissue toughness, which are thought to be good proxies for tissue longevity. SLA and LAR indicate how efficiently plants invest in light interception. Measurements of SRL and RLPM indicate how the biomass that is allocated to roots can be efficient in nutrient capture through increase of absorption surface (Markesteijn and Poorter 2009).

Leaf nutrient $\mathrm{N}, \mathrm{P}$, and $\mathrm{Ca}$ concentration was determined for three randomly selected seedlings per species per soil type. For five species (Albizia, Anadenanthera, Cedrela, Machaerium and Samanea) we selected a seedling that had a leaf dry weight $>50 \mathrm{mg}$, the minimum quantity required for leaf tissue analyses in the laboratory. Extraction of N, P and Ca were done using digestion with $\mathrm{H}_{2} \mathrm{SO}_{4}$, Se, and salicylic acid (Novozamsky et al. 1983). After digestion, $\mathrm{N}$ and $\mathrm{P}$ content was measured with a continuous-flow analyzer (SAN Plus Segmented Flow Analyser Skalar SA-4000, Skalar UK, York, UK), and Ca content was measured using an Atomic Absorption Spectrometer (AASVarian Spectra AA-600, Varian, Palo Alto, USA). Chemical tissue analyses were done at the facilities of Wageningen University, The Netherlands. 
Data analyses We quantified survival percentage for each species by dividing the number of seedlings alive at the time of the second harvest by the number of transplanted seedlings. We compared survival percentage between soil types using a chi-square test. Relative height growth rate (RGRh) was calculated for each seedling as: $R G R h=\frac{\ln h_{2}-\ln h_{1}}{t_{2}-t_{1}}$, where $h_{n}$ represents the seedling height at time $n ; t_{1}$ is time at transplanting, $t_{2}$ time at harvesting, and $\left(t_{2}-t_{1}\right)$ is the number of days between transplanting and harvest. RGR based on plant biomass (RGRb) was calculated for each species using the information of both harvests as: $R G R b=\frac{\overline{\ln M_{2}}-\overline{\ln M_{1}}}{t_{2}-t_{1}}$, where $\overline{\ln }_{n}$ is the average of the natural $\log$ of the dry mass of each seedling at harvest $n$.

Continuous variables were $\log _{10}$-transformed, whereas ratios were arcsine-transformed prior to statistical analyses. To test for the effect of ADE and non-ADE on total biomass, RGRh, and plant traits, we performed a two-way ANOVA, with soil type and species as factors. For this analysis we used 13 species instead of 17 because we had significant mortality in four species that left us with few replicates per treatment to make comparisons between the two soils. We used an unbalanced design because two species (Cariniana and Hymenaea) had different number of seedlings per soil type. The interaction between soil type and species was also evaluated. For all traits but RGRh, data of the second harvest were used. The amount of variance that was explained by each factor was determined by dividing the sum of squares associated with each factor (soil or species) and their interaction by the total sum of squares of the model. A separate analysis was done for each species using one-way ANOVA, with soil type as factor. The effect of soil type on leaf production rate was tested using a non-parametric Kruskal-Wallis test because the data were not normally distributed.

We detected that the percentage of leaf $\mathrm{Ca}$ was always higher on ADE, whereas the percentages of leaf $P$ and leaf $\mathrm{N}$ were similar or lower on ADE than in nonADE, despite the higher concentration of these elements in ADE (Table 1; see results; Fig. 3). Therefore, we explore the relationships between pairs of tissue nutrient concentration ( $\mathrm{Ca}$ and $\mathrm{P}$; $\mathrm{Ca}$ and $\mathrm{N}$ ) from each soil. We averaged the $\mathrm{Ca}, \mathrm{N}$ and $\mathrm{P}$ concentration in the leaves of seedlings growing in ADE and non-ADE, and calculated the difference between these amounts in each soil type per species, as follows: Difference $A D E-n o n A D E=$ $\left(\overline{\text { Nutrient }_{i, A D E}}-\overline{\text { Nutrient }}{ }_{i, n o n-A D E}\right)$, where Nutrient stands for the concentration in the leaf, and $i$ stands for $\mathrm{Ca}, \mathrm{N}$ or
P. Using the information of all species, we performed linear regressions to test the relationship between the difference in leaf $\mathrm{Ca}\left(\mathrm{Ca}_{\mathrm{ADE}-n o n} \mathrm{ADE}\right)$ and the difference in leaf $\mathrm{P}\left(\mathrm{P}_{\mathrm{ADE}-\mathrm{nonADE}}\right)$ as well as the relationship between the difference in leaf $\mathrm{Ca}\left(\mathrm{Ca}_{\mathrm{ADE}-n o n A D E}\right)$ and the difference in leaf $\mathrm{N}\left(\mathrm{N}_{\mathrm{ADE}-\text {-nonADE }}\right)$.

Based on species leaf $\mathrm{P}$ and $\mathrm{N}$ responses to soils type(see results $y$ axes; Fig. $4 \mathrm{a}$ and b), we separated the species into the following groups: species whose differences in leaf $\mathrm{P}\left(\mathrm{P}_{\mathrm{ADE}-n o n A D E}\right)$ were positive, implying higher leaf $\mathrm{P}$ on ADE (hereafter refered as positive for $\mathrm{P}$ ); species whose differences in $\mathrm{P}$ ( $\mathrm{P}_{\mathrm{ADE}}$ nonADE) were negative, implying lower leaf $\mathrm{P}$ on $\mathrm{ADE}$ (negative for $\mathrm{P}$ ); species whose differences in leaf $\mathrm{N}$ $\left(\mathrm{N}_{\mathrm{ADE}-\mathrm{nonADE}}\right)$ were positive, implying higher leaf $\mathrm{N}$ on $\mathrm{ADE}$ (positive for $\mathrm{N}$ ); species whose differences in leaf $\mathrm{N}\left(\mathrm{N}_{\mathrm{ADE}-\mathrm{nonADE}}\right)$ were negative, implying lower leaf $\mathrm{N}$ on $\mathrm{ADE}$ (negative for $\mathrm{N}$ ). Using these four response groups, we tested how $\mathrm{Ca}$ uptake was related with $\mathrm{RGRb}$. We evaluated $\mathrm{Ca}$ because it was the nutrient in the leaves that consistently increased in ADE for all species (Fig. 3a). Therefore, we performed a linear regression for each response group between leaf $\mathrm{Ca}$ concentration in leaves as the independent variable and the average RGRb as the dependent variable. Finally, we also tested how $\mathrm{Ca}$ uptake was related with leaf $\mathrm{P}$ uptake or leaf $\mathrm{N}$ uptake for each response group using linear regressions. All statistical analyses were done using Genstat 16th ed. (VSN International Ltd).

\section{Results}

Eight out of 17 species showed some mortality during the experiment. Terminalia and Poeppigia had a significantly higher mortality in ADE than in non-ADE soil ( $\chi^{2}: 10.83, p<0.05 ; \chi^{2}: 12.08, p<0.05$, respectively), whereas Schizolobium had a significantly higher mortality in non-ADE $\left(\chi^{2}: 15.41, p<0.05\right)$ (Fig. 1).

\section{Plant responses to ADE}

We found significant differences between soil types for ten out of 24 traits, but the proportion of the variance explained by soils for each of these variables was very low (less than $2.8 \%$, Table 3). Species had a significant effect on all variables, explaining 35 to $96 \%$ of the variance (Table 3). 
Fig. 1 Seedling survival of 17 species of tropical trees in Amazonian Dark Earths (ADE) and non-Amazonian Dark Earth (non-ADE) soils after the growing period in the greenhouse

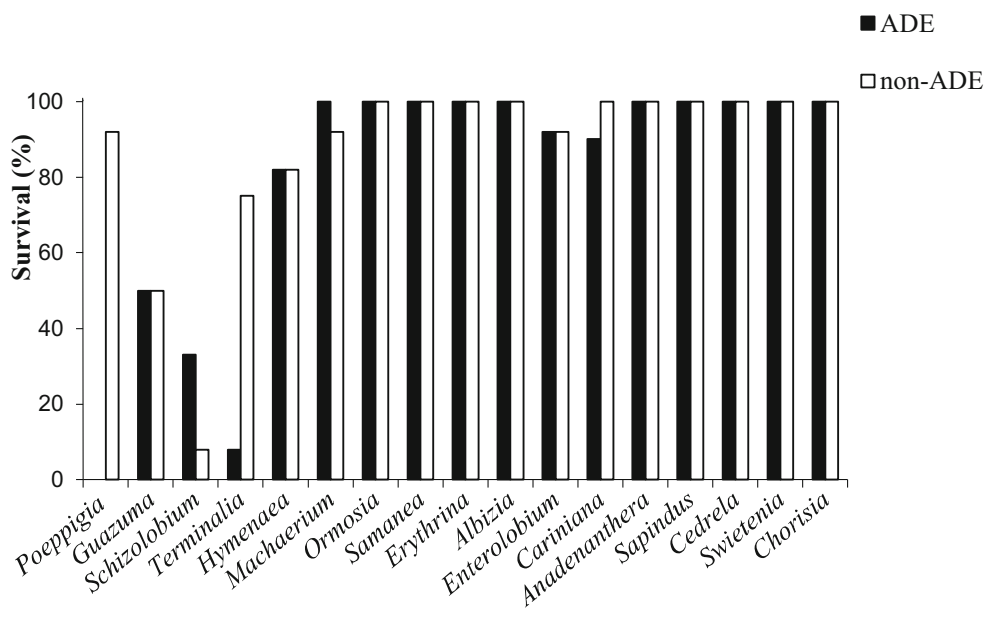

We expected soil fertility from ADE to have a positive effect on plant growth, but most of the species had a similar growth rate on both soils. Total biomass (Fig. 2a), height growth (RGRh, Fig. 2b) and biomass growth (RGRb) did not differ significantly between soil types (Table 3 ). However, the interaction between soil type and species was significant for total biomass and RGRh (Table 3), indicating that some species grew faster in ADE, whereas other species grew faster in non-ADE. Seedlings of Cedrela and Chorisia had significantly more biomass in ADE (one-way ANOVA: Cedrela $F=7.29, p=0.013$; Chorisia $F=5.40, p=0.03$ ), whereas Machaerium had a significantly higher biomass in non-ADE (one-way ANOVA, $F=4.87, p=0.039$ ) (Fig. 2a). Furthermore, Swietenia had a higher RGRh in ADE (one-way ANOVA, $F=9.04, p=0.006$ ) (Fig. 2b), whereas Chorisia had a significantly higher RGRh in non-ADE (one-way ANOVA, $F=18.88$, $p<0.001$ ).

Overall, leaf production rate was similar for both soil types (Kruskal-Walis $H=2.97 ; p=0.084$ ), although some species such as Cedrela, Chorisia, and Cariniana had a higher leaf production rate in ADE than in non-ADE, whereas Swietenia had higher leaf production rate in non-ADE soil (Online Resource 2). We found that biomass allocation to leaves (LMF) was significantly higher in ADE than in non-ADE (Table 3). There were no significant differences in biomass allocation to roots (RMF) between soil types. There was a significant interaction between soils and species in allocation to stems (SMF) (Table 3). Seedlings of Anadenanthera had heavier stems in ADE $(F=14.71$, $p<0.001)$ than in non-ADE, whereas Erythrina and
Enterolobium seedlings had heavier stems in non-ADE than in ADE (Online Resource 2). Specific leaf area (SLA, a measure of area investment per leaf mass) and leaf area investment per plant mass (LAR) were significantly higher for seedlings in ADE (Table 3). We found a significant interaction term for specific root length (SRL) (a measure of plant investment in root length) (Table 3); Enterolobium seedlings had a significantly higher SRL in ADE, whereas Swietenia seedlings had higher SRL in non-ADE (Online Resource 2). Leaf and root dry mass content were significantly higher in nonADE (Table 3). Leaf Ca concentration was significantly higher in ADE (Table 3) this was particularly the case for Ormosia, Erythrina, Albizia, and Cariniana (Fig. 3a). Leaf $\mathrm{N}$ concentration did not differ significantly between soil types (Table 3, Fig. 3b). We found a significant interaction between soil and species for leaf $\mathrm{P}$ concentration (Table 3 ), caused by a significantly higher leaf $\mathrm{P}$ concentration in $\mathrm{ADE}$ for Machaerium (one-way ANOVA, $F=8.36, p=0.04$ ) and in non-ADE for Erythrina (one-way ANOVA, $F=128.2, p<0.001$ ) (Fig. 3c).

Nutrient stoichiometry in relation with growth rates

We explored the differences in leaf nutrient concentration between seedlings growing in ADE and nonADE soils. We found that all species had a higher leaf $\mathrm{Ca}$ in ADE than non-ADE (positive values on $x$ axis, Fig. 4a), whereas species had either a higher (positive values on $y$ axis, Fig. $4 \mathrm{a}$ ) or a lower leaf $\mathrm{P}$ in ADE than in non-ADE (negative values on $y$ axis, Fig. 4a). This resulted in a significant negative 
Table 3 Averages of morphological, physiological and chemical variables measured on seedlings of 13 species of tropical trees growing on $\operatorname{ADE}(n=12$ seedlings per species) and non-ADE soils ( $n=12$ seedlings per species)

\begin{tabular}{|c|c|c|c|c|c|c|c|c|c|c|c|c|}
\hline \multirow[t]{2}{*}{ Trait } & \multirow[b]{2}{*}{$\mathrm{ADE}$} & \multirow[b]{2}{*}{ N-ADE } & \multirow[b]{2}{*}{$\mathrm{R}^{2}$} & \multicolumn{3}{|l|}{ Soil } & \multicolumn{3}{|l|}{ Species } & \multicolumn{2}{|c|}{ Soil x Species } & \multirow[b]{2}{*}{ SSsxspp/SSt } \\
\hline & & & & $\mathrm{F}$ & $\mathrm{p}$ & $\mathrm{SSs} / \mathrm{SSt}$ & $\mathrm{F}$ & $\mathrm{p}$ & $\mathrm{SSspp} / \mathrm{SSt}$ & $\mathrm{F}$ & $\mathrm{p}$ & \\
\hline Biomass (g) & 0.932 & 0.94 & 0.89 & 0.39 & 0.531 & 0.0002 & 184.11 & $<.001$ & 0.88 & 3 & $<.001$ & 0.014 \\
\hline $\mathrm{RGRh}\left(\mathrm{mm} \cdot \mathrm{mm} \cdot \mathrm{d}^{-1}\right)$ & 0.043 & 0.042 & 0.87 & 0.09 & 0.767 & 0.0000 & 147.47 & $<.001$ & 0.84 & 6.53 & $<.001$ & 0.037 \\
\hline RGRb (g.g.d $\left.{ }^{-1}\right)$ & 0.016 & 0.016 & - & 0.005 & 0.944 & 0.0000 & - & - & - & - & - & - \\
\hline Root Mass Fraction (RMF) $\left(\mathrm{g} \mathrm{g}^{-1}\right)$ & 0.232 & 0.244 & 0.68 & 3.36 & 0.068 & 0.0040 & 46.54 & $<.001$ & 0.67 & 0.58 & 0.859 & 0.008 \\
\hline Stem Mass Fraction (SMF) $\left(\mathrm{g} \mathrm{g}^{-1}\right)$ & 0.255 & 0.261 & 0.67 & 1.8 & 0.181 & 0.0022 & 43.4 & $<.001$ & 0.64 & 2.15 & 0.015 & 0.032 \\
\hline Leaf Mass Fraction (LMF) $\left(\mathrm{g} \mathrm{g}^{-1}\right)$ & 0.513 & 0.494 & 0.61 & 8.06 & 0.005 & 0.0117 & 33.19 & $<.001$ & 0.58 & 1.14 & 0.331 & 0.020 \\
\hline Diameter of secondary roots (mm) & 0.481 & 0.49 & 0.61 & 0.08 & 0.776 & 0.0001 & 31.74 & $<.001$ & 0.59 & 1.24 & 0.253 & 0.023 \\
\hline Secondary to primary root mass $\left(\mathrm{g} \mathrm{g}^{-1}\right)$ & 0.897 & 0.755 & 0.38 & 2.98 & 0.086 & 0.0069 & 12.57 & $<.001$ & 0.35 & 1.05 & 0.401 & 0.029 \\
\hline Number of secondary soots & 29.17 & 30.66 & 0.53 & 1.43 & 0.233 & 0.0026 & 22.77 & $<.001$ & 0.49 & 1.66 & 0.076 & 0.036 \\
\hline Specific Root Length $\left(\mathrm{m} \mathrm{Kg}^{-1}\right)$ & 17,860 & 15,310 & 0.57 & 0.36 & 0.549 & 0.0006 & 26.88 & $<.001$ & 0.52 & 2.69 & 0.002 & 0.052 \\
\hline Root Length Ratio $\left(\mathrm{m} \mathrm{Kg}^{-1}\right)$ & 98,740 & 74,760 & 0.78 & 0.11 & 0.736 & 0.0001 & 79.19 & $<.001$ & 0.77 & 1.74 & 0.059 & 0.017 \\
\hline Root Dry Matter Content (RDMC) $\left(\mathrm{g} \mathrm{g}^{-1}\right)$ & 0.173 & 0.187 & 0.78 & 15.91 & $<.001$ & 0.0128 & 78.82 & $<.001$ & 0.76 & 0.78 & 0.672 & 0.008 \\
\hline Stem Dry Matter Content (SDMC) $\left(\mathrm{g} \mathrm{g}^{-1}\right)$ & 0.282 & 0.293 & 0.91 & 7.81 & 0.006 & 0.0027 & 218.1 & $<.001$ & 0.90 & 2.12 & 0.016 & 0.009 \\
\hline Leaf Dry Matter Content (LDMC) $\left(\mathrm{g} \mathrm{g}^{-1}\right)$ & 0.27 & 0.279 & 0.96 & 14.98 & $<.001$ & 0.0022 & 551.38 & $<.001$ & 0.96 & 0.98 & 0.464 & 0.002 \\
\hline Stem Density $\left(\mathrm{g} \mathrm{cm}^{-3}\right)$ & 0.31 & 0.316 & 0.90 & 1.6 & 0.207 & 0.0006 & 188.95 & $<.001$ & 0.89 & 1.93 & 0.031 & 0.009 \\
\hline Specific Leaf Area (SLA) $\left(\mathrm{m}^{2} \mathrm{Kg}^{-1}\right)$ & 41.66 & 39.46 & 0.74 & 4.8 & 0.029 & 0.0046 & 63.23 & $<.001$ & 0.73 & 0.83 & 0.624 & 0.010 \\
\hline Leaf Area Ratio (LAR) $\left(\mathrm{m}^{2} \mathrm{Kg}^{-1}\right)$ & 18.83 & 17.27 & 0.61 & 9.54 & 0.002 & 0.0140 & 32.52 & $<.001$ & 0.57 & 1.17 & 0.306 & 0.021 \\
\hline Force to Punch $\left(\mathrm{N} \mathrm{mm}^{-1}\right)$ & 0.229 & 0.244 & 0.69 & 4.31 & 0.039 & 0.0065 & 49.62 & $<.001$ & 0.68 & 0.88 & 0.543 & 0.012 \\
\hline Leaf Thickness (mm) & 0.123 & 0.124 & 0.90 & 1.01 & 0.315 & 0.0005 & 202.28 & $<.001$ & 0.89 & 1.87 & 0.058 & 0.008 \\
\hline Leaf $\mathrm{Ca}$ concentration $\left(\mathrm{mg} \mathrm{g}^{-1}\right)$ & 19.2 & 16.8 & 0.95 & 26.52 & $<.001$ & 0.0278 & 71.3 & $<.001$ & 0.90 & 1.67 & 0.102 & 0.021 \\
\hline Leaf $\mathrm{N}$ concentration $\left(\mathrm{mg} \mathrm{g}^{-1}\right)$ & 34.7 & 35.4 & 0.95 & 1.35 & 0.251 & 0.0012 & 88.88 & $<.001$ & 0.94 & 0.87 & 0.579 & 0.009 \\
\hline Leaf $\mathrm{P}$ concentration $\left(\mathrm{mg} \mathrm{g}^{-1}\right)$ & 1.9 & 2.1 & 0.90 & 6.78 & 0.012 & 0.0134 & 32.42 & $<.001$ & 0.77 & 5.02 & $<.001$ & 0.119 \\
\hline $\mathrm{Ca}: \mathrm{P}$ & 11.06 & 9.95 & 0.83 & 3.74 & 0.059 & 0.0124 & 18.73 & $<.001$ & 0.74 & 1.79 & 0.075 & 0.071 \\
\hline $\mathrm{Ca}: \mathrm{N}$ & 0.59 & 0.51 & 0.94 & 22.58 & $<.001$ & 0.0258 & 65.31 & $<.001$ & 0.90 & 1.41 & 0.191 & 0.019 \\
\hline $\mathrm{N}: \mathrm{P}$ & 20.51 & 19.84 & 0.83 & 0.41 & 0.522 & 0.0013 & 19.86 & $<.001$ & 0.77 & 1.52 & 0.146 & 0.059 \\
\hline
\end{tabular}

The overall $\mathrm{r}^{2}$ of the model and the ANOVA results are provided. The effect of soil, species or the interaction is presented with their $\mathrm{F}$ values and their significance level. The percentage of variation explained by each factor $\left(\mathrm{SS}_{\mathrm{factor}} / \mathrm{SS}_{\text {total }}\right)$ or the interaction was calculated as the ratio between the factor sum of squares or interaction sum of squares and total sum of squares; thus, variation explained by soils $\left(\mathrm{SS}_{\mathrm{s}} / \mathrm{SS}_{\mathrm{t}}\right)$, variation explained by species $\left(\mathrm{SS}_{\mathrm{spp}} / \mathrm{SS}_{\mathrm{t}}\right)$, variation explained by the interaction between soil and species $\left(\mathrm{SS}_{\mathrm{sxsp}} / \mathrm{SS}_{\mathrm{t}}\right)$

relationship between the difference in leaf $\mathrm{Ca}$ concentration ( $\mathrm{Ca}_{\mathrm{ADE}}$-nonADE $)$ and the concomitant difference in leaf $\mathrm{P}$ concentration $\left(\mathrm{P}_{\mathrm{ADE}-\text { nonADE }}\right)$ (Fig. 4a). A similar trend was found for leaf $\mathrm{Ca}$

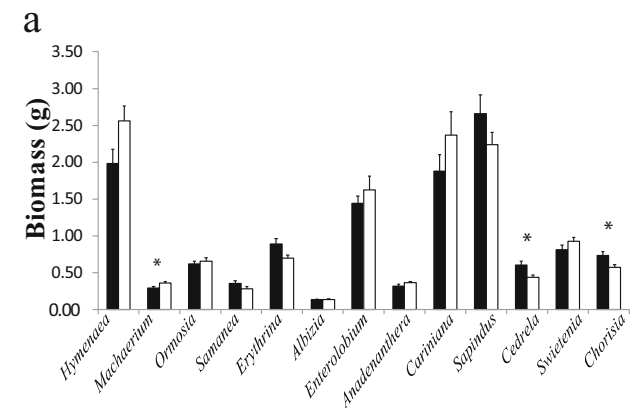

Fig. 2 Biomass at final harvest (a) and relative height growth rate (RGRh) (b) of seedlings of 13 species growing in Amazonian Dark Earth (ADE) (black bars) and non-Amazonian Dark Earths

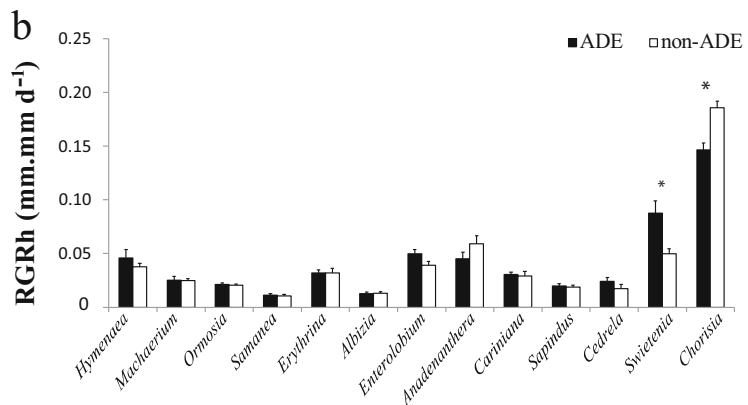

(open bars). Means and standard errors are shown. Asterisks indicate significant differences between soils at the species level $(p \leq 0.05)$ 


\section{a}

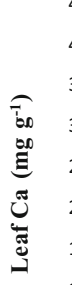

45
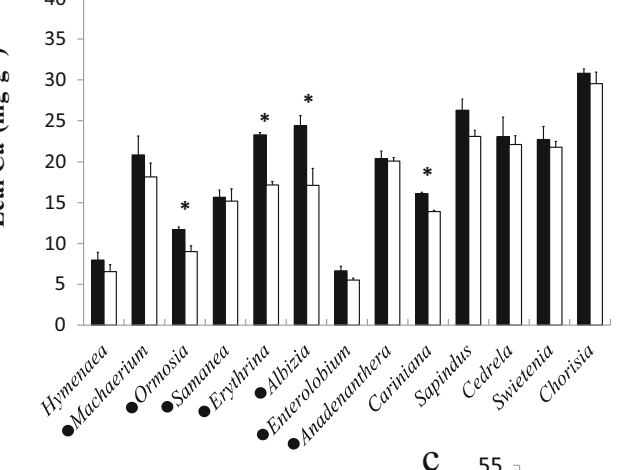

b

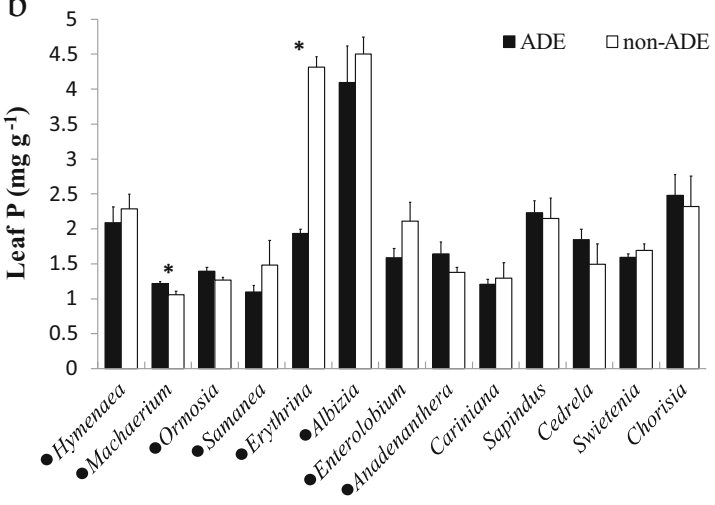

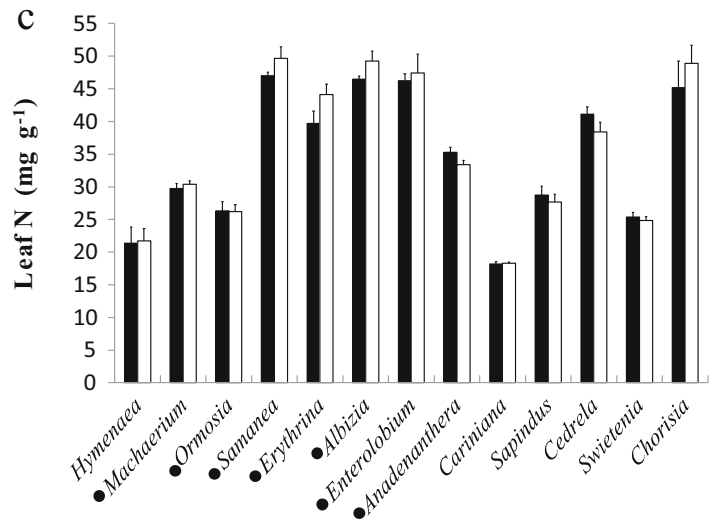

Fig. 3 Leaf calcium (a), phosphorus (b) and nitrogen (c) concentrations of seedlings of 13 tropical tree species growing in Amazonian Dark Earths soils (black bars) and non-Amazonian Darks Earth soils (open bars). Six seedlings per species were used per

concentrations $\left(\mathrm{Ca}_{\mathrm{ADE}-\mathrm{nonADE}}\right)$ and leaf $\mathrm{N}$ concentration $\left(\mathrm{N}_{\mathrm{ADE}-n o n A D E}\right)$ (Fig. 4); species showed either a higher (positive values on $y$ axis, Fig. 4b) or a lower leaf $\mathrm{N}$ concentration in ADE than in non-ADE soils (negative values on $y$ axis, Fig. 4b). The latter relationship, however, was only a trend, but not statistically significant $(P=0.086$, Fig. $4 b)$. It is worth to notice that most of the species located in the negative side of the $y$ axis, where $\mathrm{N}$-fixing legumes (Fig. 4a and b). We also found a positive relationship between the difference in leaf $\mathrm{P}$ and leaf $\mathrm{N}$ concentrations in ADE and non-ADE (Fig. 4c).

The relationship between leaf $\mathrm{Ca}$ concentration and $\mathrm{RGRb}$ showed that "positive for P" species increase in $\mathrm{RGRb}$ with increasing leaf $\mathrm{Ca}$ concentration (Adj$\mathrm{R}^{2}: 0.64 ; p=0.034$ ) (Fig. 5a), but no relationship was found for "negative for $\mathrm{P}$ " species, $\left(\operatorname{Adj}-\mathrm{R}^{2}: 0.09 ; p=\right.$ 0.26) (Fig. 5a). Besides, we found that in "positive for $\mathrm{P}$ " species, leaf $\mathrm{P}$ concentration increased with leaf $\mathrm{Ca}$ concentration, although this was at the edge of soil type. Species that are marked with a black point $(\bullet)$ are $\mathrm{N}$ fixing legumes reported on Table 1. Bars represent the average per soil type, with standard errors. Asterisks indicate significant differences between the two soils (t-test, $p \leq 0.05$ )

significance (Adj- $\mathrm{R}^{2}: 0.56 ; p=0.052$ ); but no relationship was found for "negative for $\mathrm{P}$ " species (Adj- $\mathrm{R}^{2}:-0.04$; $p=0.42$ ) (Fig. 5b). Likewise, the relationship between leaf $\mathrm{Ca}$ concentration and RGRb showed that "positive for N" species increase in RGRb with increasing leaf $\mathrm{Ca}$ concentration (Adj- $\mathrm{R}^{2}: 0.86 ; p=0.01$ ), but no relationship was found for "Negative for N" (Adj- $\mathrm{R}^{2}: 0.24 ; p=0.12$ ) (Fig. 5c). Furthermore, we found that there was not significant relationship between leaf $\mathrm{Ca}$ concentration and leaf $\mathrm{N}$ concentration neither in "positive for $\mathrm{N}$ " species (Adj- $\mathrm{R}^{2}: 0.47 ; p=0.12$ ), nor "Negative for N" species (Adj-R" : $0.05 ; p=0.46$ ) (Fig. $5 d$ ).

\section{Discussion}

The aim of this study was to evaluate whether tropical tree seedlings respond to the differences in nutrient concentrations between ADE and non-ADE. Seedlings indeed adjusted their morphology and tissue chemistry 

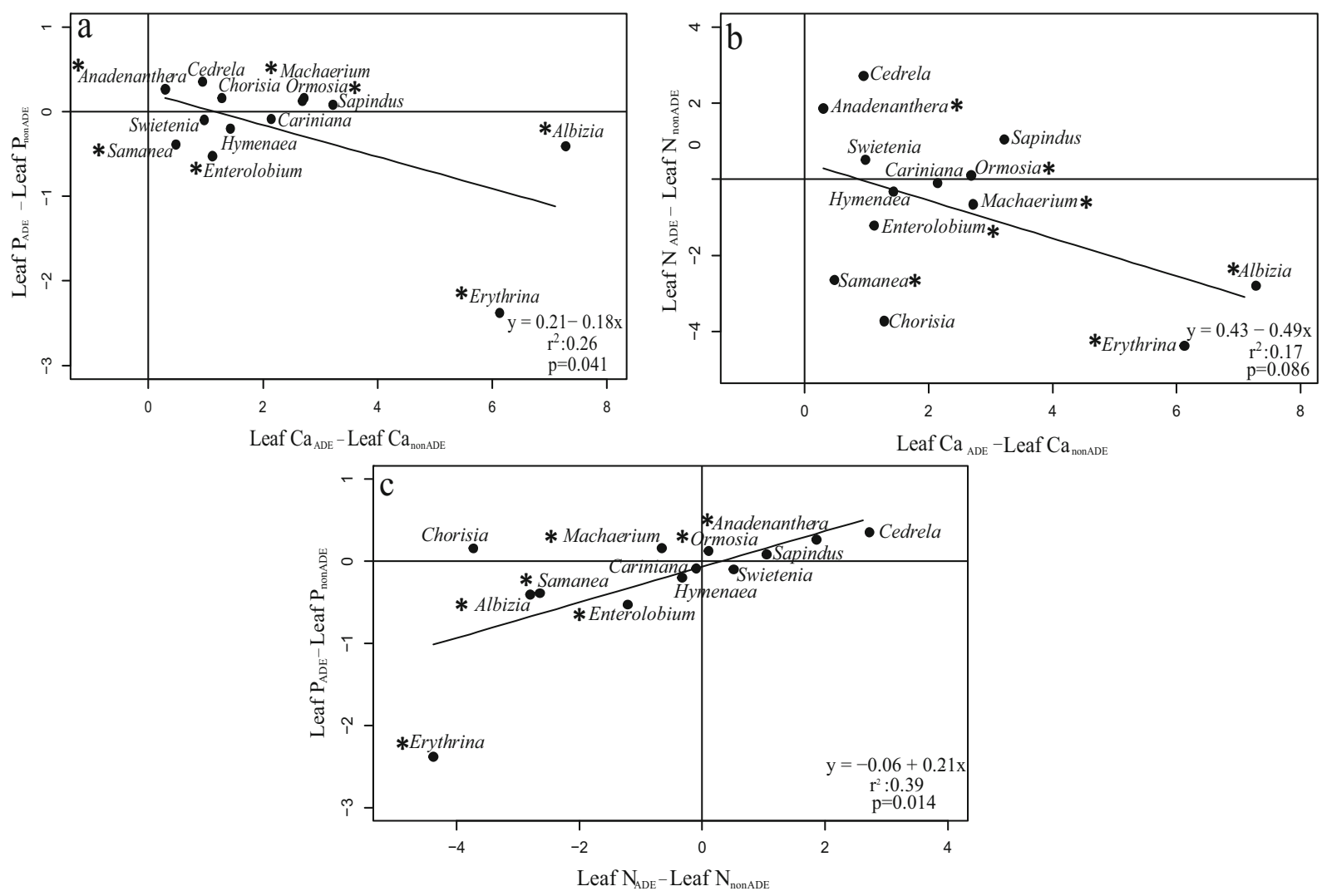

Fig. 4 Linear regressions of the differences in leaf nutrient concentrations between Amazonian Dark Earth and non-Amazonian Dark Earths. (a) Differences in leaf P against differences in leaf Ca. (b) Differences in leaf $\mathrm{N}$ concentration against differences in leaf $\mathrm{Ca}$ concentration; (c) Differences in leaf $\mathrm{P}$ concentration

in response to the increased fertility in ADE, but this did not lead to higher seedling growth in ADE. This lack of growth response seems to be determined by the interplay between the uptake of $\mathrm{Ca}$ and the uptake of other essential nutrients such as $\mathrm{N}$ and $\mathrm{P}$.

\section{Plant responses to ADE}

In our study we found lower survival in seedlings of Poeppigia and Terminalia that were growing in ADE, compared to those growing on non-ADE. Seedlings of Poeppigia were not able to develop a root system on $\mathrm{ADE}$ and the seedlings that could establish on non-ADE showed some chlorosis (E. Quintero, personal observation). These characteristics can be associated with inability of plants to regulate $\mathrm{Ca}$ uptake when they grow in soil with high $\mathrm{Ca}$. Studies in calcifuges species have suggested that excess of $\mathrm{Ca}$ in the tissues translate to $\mathrm{Ca}$ toxicity, that inhibits growth, and causes mortality against differences in leaf $\mathrm{N}$ concentration. Species that are maked with an asterisk $\left(^{*}\right)$ are $\mathrm{N}$-fixing legumes reported in Table 1. Results of linear regression are provided. Concentrations units are $\mathrm{mg} \mathrm{g}^{-1}$

(Jefferies and Willis 1964). This inhibition could be caused by metabolic disorders related to enzyme inactivation and to a decrease of $\mathrm{P}$ availability for metabolism due to the excess of cytosolic Ca (Grundon 1972; Jefferies and Willis 1964; Zohlen and Tyler 2004).

We predicted that in high-fertility ADE, plants would invest in aboveground light capture, whereas in the nonADE, plants would invest in belowground nutrient capture. This is in line with Brower's hypothesis which states that plants invest in capturing the resource that is in most limiting supply (Brouwer 1962). We found that seedlings growing on ADE allocated more biomass to leaves (LMF) than seedlings on non-ADE, but we did not find support for higher investment in root biomass on non-ADE. Additionally, we found higher investment in leaf area per leaf mass (SLA) and per plant mass (LAR) on ADE. Greater biomass allocation to leaves in combination with higher SLA and LAR on ADE (Table 3 ) could increase seedlings capacity to capture 

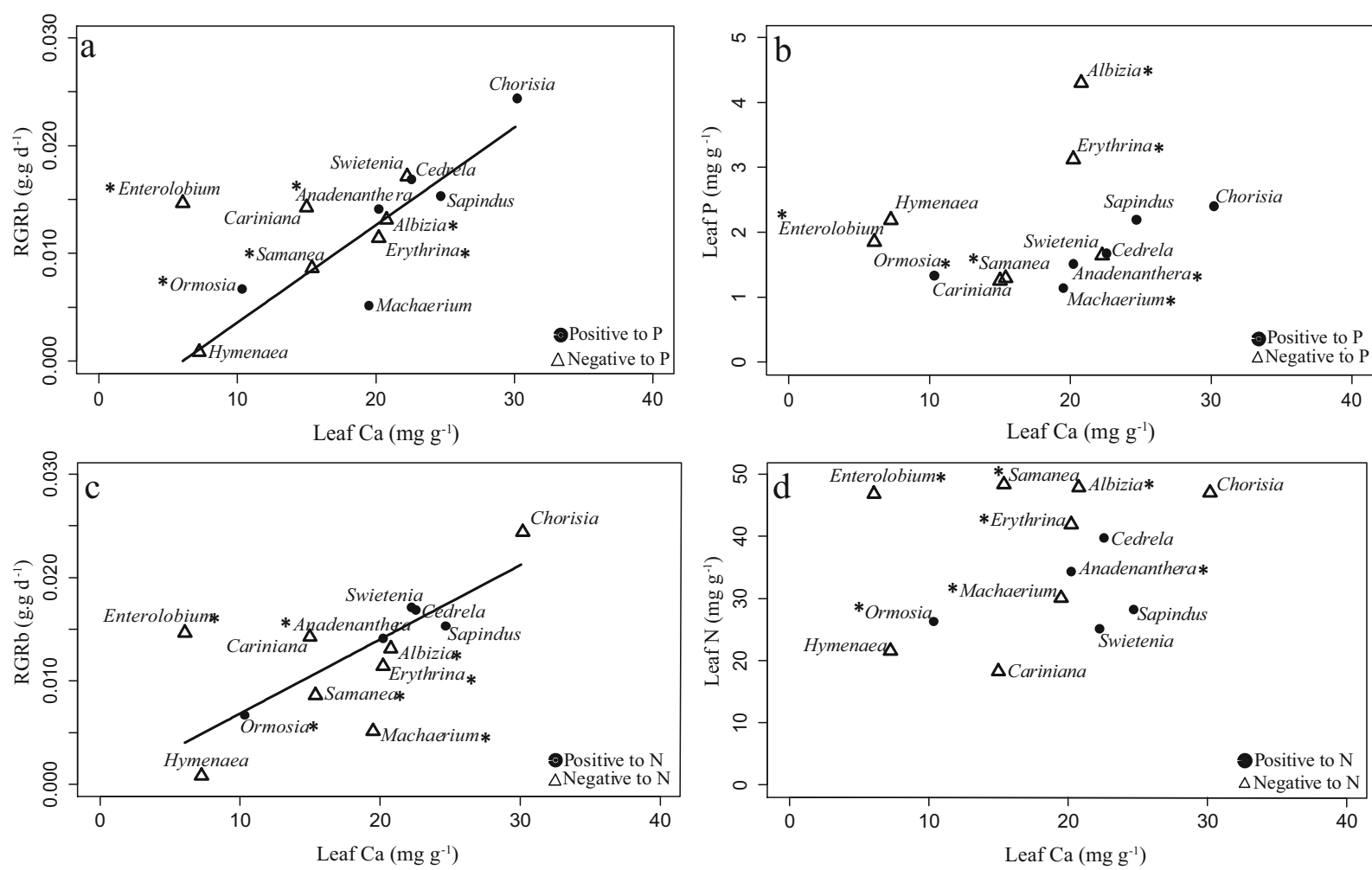

Fig. 5 Relation between (a) Relative biomass growth rate $(\mathrm{RGRb})$ and leaf Ca concentration; (b) Leaf $\mathrm{P}$ concentration and leaf $\mathrm{Ca}$ concentration for species that responded positively or negatively to $\mathrm{P}$. The regression line represent the significant relationship between $\mathrm{RGRb}$ and leaf $\mathrm{Ca}$ only for species that were "positive for $\mathrm{P}$ " $(\mathrm{RGRb}=-0.0054+0.009$ (leaf $\mathrm{Ca}) ; \mathrm{R}^{2}=0.64 ; p=$ 0.034). (c) Relation between relative biomass growth rate (RGRb) and leaf $\mathrm{Ca}$ concentration; (d) Leaf $\mathrm{P}$ concentration and leaf $\mathrm{Ca}$

light and should enhance biomass growth (Poorter 1999). However, in our experiment, seedling RGR was similar on both soil types, suggesting that an increase in leaf light capture capacity does not translate into faster growth. There are other factors, such as leaf tissue chemistry that could explain the observed limitation of seedling growth found in this study (Figs. 4 and 5).

High $\mathrm{Ca}$ in ADE soils affect leaf nutrient stoichiometry

One of the most interesting results of our study is the effect of ADE on leaf nutrient concentrations of some of the most important elements for plant growth. ADE were more fertile, and had 3.2 times more P, 2.4 times more $\mathrm{Ca}$, and 1.6 times more $\mathrm{N}$ compared with the nonADE (Table 2). All species had indeed higher leaf $\mathrm{Ca}$ on ADE than on non-ADE (Fig. 3a), but only 6 out of 13 species had higher leaf P and leaf $\mathrm{N}$ on ADE (Figs. 3b, c

concentration for species that responded positively or negatively to $\mathrm{N}$. The regression line represents the significant relationship between $\mathrm{RGRb}$ and leaf $\mathrm{Ca}$ only for species that were "positive for $\mathrm{N}$ " $\left(\mathrm{RGRb}=-0.0003+0.0071(\right.$ Leaf $\left.\mathrm{Ca}) ; \mathrm{R}^{2}=0.86 ; p=0.014\right)$. Relationships used information of 13 tree seedling species. Species that are marked with asterisk $(*)$ are $\mathrm{N}$-fixing legumes reported in Table 1

and $4 \mathrm{a}, \mathrm{b})$. Seedlings of seven species had, on average, 1.3 times higher leaf $\mathrm{P}$ concentrations on non-ADE than on ADE, even though ADE had more $\mathrm{P}$ than non-ADE soils (Table 2). This result suggests that there is an imbalance between soil and tissue elements in some of the species that we studied. There are several possible explanations for this result that are related with soil chemistry and plants nutrient stoichiometry: first the effects of high $\mathrm{Ca}$ in soils and its consequences for $\mathrm{P}$ availability, second the effects of a high Ca supply on plant tissue and the interaction with inorganic $\mathrm{P}$, and finally, a decrease in N-fixation leading to a decrease in $\mathrm{P}$ uptake by $\mathrm{N}$-fixer species on ADE.

Firstly, soils that combine a neutral to alkaline $\mathrm{pH}$ with a high $\mathrm{Ca}$ concentration (as it is the case in this Bolivian forest) may have, in fact, a low effective availability of P. The relatively high Ca in ADE could lead to the formation of mineral insoluble calcium phosphate, 
thus reducing $\mathrm{P}$ availability as it is reported in calcareous soils with pH around 7.8 (Lee 1998; Yang and Jacobsen 1990; Zohlen and Tyler 2004). In spite of higher plant available P extracted on ADE (Table 2), lower or not increase in seedlings leaf $P$ could suggest some decrease in effective $\mathrm{P}$ availability due to $\mathrm{P}$ bounded to $\mathrm{Ca}$ (Yang and Jacobsen 1990). In such conditions, only species that can exude organic acids into the rhizosphere to increase the solubility of phosphate would be able to incorporate more $\mathrm{P}$ from the soil, as it has been shown in other studies (White and Broadley 2003). Further studies on the interactions between soil $\mathrm{Ca}$ and $\mathrm{P}$ on $\mathrm{ADE}$ could improve our understanding of $\mathrm{P}$ effective availability on those soils. Especially, because the major changes in soil chemistry on ADE is due to increases of $\mathrm{Ca}$ and $\mathrm{P}$ (Glaser and Birk 2012).

Secondly, high concentrations of $\mathrm{Ca}$ in the cytosol of plant cells can react with inorganic $\mathrm{P}$ and produce calcium phosphate, decreasing the concentration of $\mathrm{P}$ available for plant metabolic functions and consequently, the P concentration measured in leaves (Tyler 1996; Zohlen and Tyler 2004). Unfortunately, this mechanism has been mainly studied in temperate species that are not able to grow in calcareous soils with high soil $\mathrm{Ca}$ concentrations (i.e. calcifuge species). In the species used in this study this mechanism is speculative but, based in our results, we consider that it deserves further exploration. (Glaser and Birk 2012)

Third, some of the species belonging to Fabaceae (e.g., Erythrina, Samanea, and Albizia) might have increased $\mathrm{N}$-fixation and higher P-uptake on non-ADE than on ADE. Presence of nodules have been reported for these species (Table 1). They had either a higher proportion of seedlings with nodules, or a higher number of nodules per root on seedlings growing on nonADE than on ADE (data not shown). Thus, more nodules can increase $\mathrm{N}$-fixation, that can increase $\mathrm{P}$ and $\mathrm{N}$ uptake on non-ADE (Fig. $3 b$ and c). Recent studies suggests that $\mathrm{N}$-fixers can increase the ability of $\mathrm{P}$ uptake by being able to invest more carbon for either association with mycorrhizal fungi or phosphatase release into the soil which can give them advantages to incorporate P (Nasto et al. 2014); nodulation process requires, in general, increase in soil $\mathrm{pH}$, usually from acid to close to neutral (Epstein and Bloom 2005; Tisdale et al. 1985). Nevertheless, few studies have shown effects of soil $\mathrm{pH} \geq 7$ on legume productivity. Three out of nine tropical herbaceous legumes from Australia showed lower productivity as a consequence of liming that increased soil $\mathrm{pH}(>6.0)$ and soil $\mathrm{Ca}$ (Munns and Fox 1977). Besides, studies on effects of liming on crop legumes such as pigeon peas (Cajanus cajan) showed a decrease in nodule weight and enzymatic activity with increase in soil $\mathrm{pH}$ from 4 to 6 (Ogata et al. 1988). Our results indicate that the nodulation process could be affected by increases in soil $\mathrm{pH}$ and Ca, on Erythrina, Samanea, and Albizia but we still need a better understanding of the environmental conditions that control the process of $\mathrm{N}$-fixation in tropical trees in order to better understand this mechanism.

Leaf Ca predicts species growth, but only for those species that can cope with $\mathrm{Ca}$ excess

Growth of seedlings in this experiment did not appear to be nutrient limited. In both soil types, seedlings had higher leaf $\mathrm{Ca}$ and $\mathrm{N}$ concentration, (Table 3) than reference levels normally found $\left(5 \mathrm{mg} \mathrm{g}^{-1}\right.$ dry mass for $\mathrm{Ca} ; 15 \mathrm{mg} \mathrm{g}^{-1}$ dry mass for $\mathrm{N}$ ) to sustain plant growth (Epstein and Bloom 2005). On the other hand, leaf $\mathrm{P}$ concentrations were close to reference values ( $2 \mathrm{mg} \mathrm{g}^{-1}$ dry mass ) (Epstein and Bloom 2005), with some exceptions such as Erytrhina $\left(4.3 \mathrm{mg} \mathrm{g}^{-1}\right.$ dry mass) and Albizia (4.5 $\mathrm{mg} \mathrm{g}^{-1}$ dry mass) (Fig. 3b). But this "luxurious" nutrient consumption of $\mathrm{Ca}, \mathrm{N}$ and $\mathrm{P}$ did not translate into higher RGR for these species (Fig. 2b). Lack of changes in plant growth with increased nutrient availability in ADE seems to be associated with species-specific abilities in tissue nutrient regulation: whereas some species increased RGR when leaf $\mathrm{Ca}, \mathrm{P}$ and $\mathrm{N}$ increased simultaneously (Fig. 5a-d), other species increased leaf $\mathrm{Ca}$ with no consequences on leaf $\mathrm{N}$ or $\mathrm{P}$ and RGR (Fig. 5a-d). This implies that increases of $\mathrm{Ca}$ in the soils and in plant tissues are not beneficial for some species. In general, $\mathrm{Ca}$ enters the plants by diffusing among cells or through cell cytoplasm in the roots, then it goes to the xylem and accumulates in the leaves (White 2012). Plants that are not adapted to high $\mathrm{Ca}$ in the soils (such as calcifuge plants) cannot regulate the excess of $\mathrm{Ca}$ entering their tissues. This excess of $\mathrm{Ca}$ uptake is done at the expense of other ion uptake such as such as $\mathrm{K}, \mathrm{Fe}$ and $\mathrm{Mg}$, causing nutritional imbalance (Jefferies and Willis 1964). We cannot confirm if whether our plants had a nutritional imbalance, since we did not measure other nutrients in the leaves, although we did not notice any symptoms of nutrient deficiency. Additionally, excess of $\mathrm{Ca}$ can induce some metabolic problems. The excess of cytosolic 
Ca can decrease cellular free P necessary for metabolic functions (Zohlen and Tyler 2004) or it can inhibit some enzymatic action by competing with enzyme cofactors such as $\mathrm{Mg}$ and manganese (Mn) (Jefferies and Willis 1964; Webb 1999). Unless plants are able to regulate the excess of Ca through storing it in the vacuole or cell wall (Kinzel 1989) or in epidermal cells or structures such as trichomes (Webb 1999), it is very likely that Ca can produce some metabolic dysfunctions. This has been suggested in studies that report poor plant development on soils with high concentrations of $\mathrm{Ca}$ (Jefferies and Willis 1964; Lee 1998).

Trees at La Chonta do not seem to be nutrient limited since natural soils are fertile in terms of $\mathrm{N}, \mathrm{P}, \mathrm{Ca}$ and $\mathrm{pH}$ (with average values $>6.5$ ). The improvement to the soil by increasing $\mathrm{Ca}$ and $\mathrm{P}$ levels, as it is the case in ADE, does not result in higher tree RGR, and it can be even detrimental for some tree species such as Terminalia and Poeppigia that seemed to suffered from Ca toxicity. Our results suggest "luxury" consumption of $\mathrm{Ca}$ by tree seedlings, but the advantages of this consumption depend on plant ability to maintain the balance among various nutrients needed for normal function. On one hand, it is likely that the species that did not improve RGR on ADE such as Samanea, Erythrina and Albizia are unable to keep levels of $\mathrm{Ca}$ that do not affect leaf $\mathrm{P}$ and $\mathrm{N}$ balance. On the other hand, species that had a higher RGR on ADE soils, such as Cedrela, and Sapindus, are able to keep levels of Ca that do not affect the balance with leaf $\mathrm{P}$ and $\mathrm{N}$ concentrations on ADE. Nevertheless, we did not elucidate the exact mechanism of Ca accumulation or detoxification (He et al. 2014). In general, our results suggest plant responses that could hamper species establishment on sites with high soil $\mathrm{Ca}$ and $\mathrm{pH}$, contributing to understand soil factors that drive species distribution.

\section{Concluding remarks}

Past inhabitants of the La Chonta forest modified the soils by increasing mostly $\mathrm{Ca}$ and $\mathrm{P}$ on ADE. Contrary to our expectation, this soil enrichment did not lead to a general increases in tree growth, probably because the background soil fertility of non-ADE at La Chonta is already high. Our results suggest three possible ways in which increase in soil $\mathrm{pH}$ and $\mathrm{Ca}$ could affect seedling growth: first, the effects of high $\mathrm{Ca}$ in soils could decrease soil $\mathrm{P}$ availability for plants; second, high $\mathrm{Ca}$ concentrations in plant tissues could decrease the availability of cytosolic inorganic $\mathrm{P}$ for metabolic purposes; and third, an increment in soil $\mathrm{pH}$ could cause decrease in $\mathrm{N}$-fixation leading to a decrease in $\mathrm{P}$ uptake by $\mathrm{N}$-fixing species on ADE. Therefore, the ability of plants to colonize and grow in patches of ADE depends on their ability to cope with increases in soil nutrients, especially increases in $\mathrm{Ca}$.

In the Amazon basin, sites where the natural soils are nutrient limited, ADE soils can improve conditions for plant growth whereas sites where nutrients in the soils are not limited, ADE potentially could cause nutrient imbalance that do not improve plant growth.

Acknowledgments This research is part of the Terra Preta Program of Wageningen University funded by the Interdisciplinary Research and Education Fund (INREF). La Chonta Company provided us permits and logistic support to work in the concession. We thank our field assistant Ricardo Mendez, forest engineer Juan Carlos Licona and the students Delma Sarmiento, Miguel Angel Fernandes and Veronica Sipepe for their help in the field, in the greenhouse and in trait measurements. We deeply thank IBIF staff for logistic facilities in Santa Cruz. Finally, we thank Agustí Muñoz-Garcia, and Hans Lambers for valuable comments that helped to improve this manuscript.

Open Access This article is distributed under the terms of the Creative Commons Attribution 4.0 International License (http:// creativecommons.org/licenses/by/4.0/), which permits unrestricted use, distribution, and reproduction in any medium, provided you give appropriate credit to the original author(s) and the source, provide a link to the Creative Commons license, and indicate if changes were made.

\section{References}

Ågren GI (2004) The C: N: P stoichiometry of autotrophs-theory and observations. Ecol Lett 7:185-191

Aranwela N, Sanson G, Read J (1999) Methods of assessing leaffracture properties. New Phytol 144:369-383

Baraloto C, Bonal D, Goldberg DE (2006) Differential seedling growth response to soil resource availability among nine neotropical tree species. J Trop Ecol 22:487-497. doi:10. 1017/s0266467406003439

Barberi A, Carneiro MA, Moreira FM, Siqueira JO (1998) Nodulação em leguminosas florestais em viveiros no sul de Minas Gerais. Cerne 4:145-153

Baribault TW, Kobe RK, Finley AO (2012) Tropical tree growth is correlated with soil phosphorus, potassium, and calcium, though not for legumes. Ecol Monogr 82:189-203

Brenes-Arguedas T, Roddy AB, Kursar TA (2013) Plant traits in relation to the performance and distribution of woody species in wet and dry tropical forest types in Panama. Funct Ecol 27: 392-402 
Brouwer R (1962) Nutritive influences on the distribution of dry matter in the plant. Neth J Agric Sci Mededeling / Instituut voor biologisch en scheikundig onderzoek van landbouwgewassen

de Faria SM, de Lima HC (1998) Additional studies of the nodulation status of legume species in Brazil. Plant Soil 200:185192. doi:10.1023/a:1004365121077

Doughty CE, Metcalfe DB, da Costa MC, de Oliveira AA, Neto G, Silva JA, Aragão LE, Almeida SS, Quesada CA, Girardin CA (2014) The production, allocation and cycling of carbon in a forest on fertile terra preta soil in eastern Amazonia compared with a forest on adjacent infertile soil. Plant Ecol Divers 7:41-53

Epstein E, Bloom AJ (2005) Mineral nutrition of plants: principles and perspectives. Massachusetts, USA

Falcão N, Moreira A, Briam Comenford N (2009) A Fertilidade dos solos de Terra Preta de Indio da Amazonia Central. In: WG Teixeira, DC Kern, B Ma'dari, HN Lima, WI Woods (eds) As Terras Pretas do Indio da Amazonia: Sua Caractericao e uso deste Conhecimento na Creacao de Novas Areas Embrapa Amazonia Occidental, Manaos

Frioni L, Rodriguez A, Meerhoff M (2001) Differentiation of rhizobia isolated from native legume trees in Uruguay. Appl Soil Ecol 16:275-282

George E, Horst W, Neumann E (2012) Adaptation of plants to adverse chemical soil conditions. Marschner's Mineral Nutrition of Higher Plants. Academic, London

German LA (2003) Historical contingencies in the coevolution of environment and livelihood: contributions to the debate on Amazonian Black Earth. Geoderma 111:307-331

Glaser B (2007) Prehistorically modified soils of central Amazonia: a model for sustainable agriculture in the twenty-first century. Philos Trans R Soc Lond 362:187196. doi:10.1098/rstb.2006.1978

Glaser B, Birk JJ (2012) State of the scientific knowledge on properties and genesis of Anthropogenic Dark Earths in Central Amazonia (terra preta de Índio). Geochim Cosmochim Acta 82:39-51. doi:10.1016/j.gca.2010.11.029

Glaser B, Lehmann J, Zech W (2002) Ameliorating physical and chemical properties of highly weathered soils in the tropics with charcoal - a review. Biol Fertil Soils 35:219-230. doi: 10.1007/s00374-002-0466-4

Grundon N (1972) Mineral nutrition of some Queensland heath plants. The Journal of Ecology: 171-181

He H, Veneklaas EJ, Kuo J, Lambers H (2014) Physiological and ecological significance of biomineralization in plants. Trends Plant Sci 19:166-174. doi:10.1016/j.tplants.2013.11.002

Hoorn C, Wesselingh FP, ter Steege H, Bermudez MA, Mora A, Sevink J, Sanmartín I, Sanchez-Meseguer A, Anderson CL, Figueiredo JP, Jaramillo C, Riff D, Negri FR, Hooghiemstra H, Lundberg J, Stadler T, Särkinen T, Antonelli A (2010) Amazonia through time: Andean uplift, climate change, landscape evolution, and biodiversity. Science 330:927-931. doi: 10.1126/science. 1194585

Jefferies R, Willis A (1964) Studies on the calcicole-calcifuge habit: II. The influence of calcium on the growth and establishment of four species in soil and sand cultures. The Journal of Ecology: 691-707

John R, Dalling JW, Harms KE, Yavitt JB, Stallard RF, Mirabello M, Hubbell SP, Valencia R, Navarrete H, Vallejo M, Foster RB (2007) Soil nutrients influence spatial distributions of tropical tree species. Proc Natl Acad Sci U S A 104:864869. doi:10.1073/pnas.0604666104
Kinzel H (1989) Calcium in the vacuoles and cell walls of plant tissue: forms of deposition and their physiological and ecological significance. Flora 182:99-125

Lambers H, Chapin FS, Pons TL (2008) Plant physiological ecology. Springer, New York

Latrubesse EM, Cozzuol M, da Silva-Caminha SAF, Rigsby CA, Absy ML, Jaramillo C (2010) The Late Miocene paleogeography of the Amazon Basin and the evolution of the Amazon River system. Earth Sci Rev 99:99-124. doi:10.1016/j. earscirev.2010.02.005

Lee JA (1998) The calcicole - calcifuge problem revisited. Adv Bot Res 29:1-30

Lima ALS, Zanella F, Schiavianto MA, Haddad CRB (2006) N availability and mechanisms of $\mathrm{N}$ conservation in deciduous and semideciduous tropical forest legume trees. Acta Bot Bras 20:625-632

Markesteijn L, Poorter L (2009) Seedling root morphology and biomass allocation of 62 tropical tree species in relation to drought- and shade-tolerance. J Ecol 97:311-325. doi:10. 1111/j.1365-2745.2008.01466.x

McDowell R, Mahieu N, Brookes P, Poulton P (2003) Mechanisms of phosphorus solubilisation in a limed soil as a function of $\mathrm{pH}$. Chemosphere 51:685-692

Metali F, Abu Salim K, Tennakoon K, Burslem DF (2015) Controls on foliar nutrient and aluminium concentrations in a tropical tree flora: phylogeny, soil chemistry and interactions among elements. New Phytol 205:280-292

Munns D, Fox R (1977) Comparative lime requirements of tropical and temperate legumes. Plant Soil 46:533-548

Nasto MK, Alvarez-Clare S, Lekberg Y, Sullivan BW, Townsend AR, Cleveland CC (2014) Interactions among nitrogen fixation and soil phosphorus acquisition strategies in lowland tropical rain forests. Ecol Lett 17:1282-1289

Navarro G, Maldonado M (2002) Geografía Ecológica de Bolivia: Vegetación y Ambientes Acuáticos. Centro de Ecología Simón I. Patiño - Departamento de Difusión, Cochabamba

Newman EI (1966) A method of estimating the total length of root in a sample. J Appl Ecol 3:139-145

Novozamsky I, Houba VJG, van Eck R, van Vark W (1983) A novel digestion technique for multi-element plant analysis. Commun Soil Sci Plant Anal 14:239-248. doi:10.1080/ 00103628309367359

Ogata S, Adu-Gyamfi J, Fujita K (1988) Effect of phosphorus and $\mathrm{pH}$ on dry matter production, dinitrogen fixation and critical phosphorus concentration in pigeon pea (Cajanus cajan (L) Millsp.). Soil Sci Plant Nutr 34:55-64

Ordoñez JC, Van Bodegom PM, Witte JPM, Wright IJ, Reich PB, Aerts R (2009) A global study of relationships between leaf traits, climate and soil measures of nutrient fertility. Glob Ecol Biogeogr 18:137-149

Ordoñez JC, van Bodegom PM, Witte JP, Bartholomeus RP, van Hal JR, Aerts R (2010) Plant strategies in relation to resource supply in mesic to wet environments: does theory mirror nature? Am Nat 175:225-239. doi:10.1086/649582

Paz-Rivera C, Putz FE (2009) Anthropogenic soils and tree distributions in a lowland forest in Bolivia. Biotropica 41:665675. doi:10.1111/j.1744-7429.2009.00521.x

Peña-Claros M, Poorter L, Alarcón A, Blate G, Choque U, Fredericksen TS, Justiniano MJ, Leaño C, Licona JC, Pariona W (2012) Soil effects on forest structure and diversity in a moist and a dry tropical forest. Biotropica 44:276-283 
Poorter L (1999) Growth responses of 15 rain-forest tree species to a light gradient: the relative importance of morphological and physiological traits. Funct Ecol 13:396-410. doi:10.1046/j. 1365-2435.1999.00332.x

Poorter H, Niklas KJ, Reich PB, Oleksyn J, Poot P, Mommer L (2012) Biomass allocation to leaves, stems and roots: metaanalyses of interspecific variation and environmental control. New Phytol 193:30-50

Quesada C, Lloyd J, Schwarz M, Patiño S, Baker T, Czimczik C, Fyllas N, Martinelli L, Nardoto G, Schmerler J (2010) Variations in chemical and physical properties of Amazon forest soils in relation to their genesis. Biogeosciences 7: 1515-1541. doi:10.5194/bg-7-1515-2010

Rasband W (2008) Bethesda, Md, USA. Image J. US National Heath Institute, Bethesda, Md, USA

Schmidt MJ, Rapp Py-Daniel A, de Paula Moraes C, Valle RBM, Caromano CF, Texeira WG, Barbosa CA, Fonseca JA, Magalhães MP, Silva do Carmo Santos D, da Silva e Silva R, Guapindaia VL, Moraes B, Lima HP, Neves EG, Heckenberger MJ (2014) Dark earths and the human built landscape in Amazonia: a widespread pattern of anthrosol formation. Journal of Archaeological Science 42: 152-165. doi: http://dx.doi.org/10.1016/j.jas.2013.11.002

Sombroek WG (1966) Amazon Soils. A Reconnissance of the Soils of the Brazilian Amazon Region. Wageningen University, Wageningen

Sprent JI, Parsons R (2000) Nitrogen fixation in legume and nonlegume trees. Field Crop Res 65:183-196

Tisdale SL, Nelson WL, Beaton JD (1985) Soil fertility and fertilizers. Macmillan Publishers, New York

Townsend AR, Cleveland CC, Asner GP, Bustamante MM (2007) Controls over foliar N: P ratios in tropical rain forests. Ecology 88:107-118

Townsend AR, Asner GP, Cleveland CC (2008) The biogeochemical heterogeneity of tropical forests. Trends Ecol Evol 23: 424-431

Tyler G (1996) Mineral nutrient limitations of calcifuge plants in phosphate sufficient limestone soil. Ann Bot 77:649-656
Viani RAG, Rodrigues RR, Dawson TE, Lambers H, Oliveira RS (2014) Soil pH accounts for differences in species distribution and leaf nutrient concentrations of Brazilian woodland savannah and seasonally dry forest species. Perspect Plant Ecol Evol Syst 16:64-74. doi:10.1016/j.ppees.2014.02.001

Vitousek PM, Porder S, Houlton BZ, Chadwick OA (2010) Terrestrial phosphorus limitation: mechanisms, implications, and nitrogen-phosphorus interactions. Ecol Appl 20:5-15. doi:10.1890/08-0127.1

Von Uexküll H, Mutert E (1995) Global extent, development and economic impact of acid soils. Plant Soil 171:1-15

Watanabe T, Broadley MR, Jansen S, White PJ, Takada J, Satake K, Takamatsu T, Tuah SJ, Osaki M (2007) Evolutionary control of leaf element composition in plants. New Phytol $174: 516-523$

Webb MA (1999) Cell-mediated crystallization of calcium oxalate in plants. Plant Cell Online 11:751-761

White PJ (2012) Ion uptake mechanisms of individual cells and roots: short-distance transport. In: Marschner P (ed) Marschner's mineral nutrition of higher plants. Academic, London

White PJ, Broadley MR (2003) Calcium in plants. Ann Bot 92: 487-511

Woods WI, Glaser B (2004) Towards an understanding of Amazonian dark earths. In: Glaser B, Woods W (eds) Amazonian dark earths: explorations in space and time. Springer, New York

Wright SJ, Yavitt JB, Wurzburger N, Turner BL, Tanner EVJ, Sayer EJ, Santiago LS, Kaspari M, Hedin LO, Harms KE, Garcia MN, Corre MD (2011) Potassium, phosphorus, or nitrogen limit root allocation, tree growth, or litter production in a lowland tropical forest. Ecology 92:1616-1625. doi:10. 1890/10-1558.1

Yang JE, Jacobsen JS (1990) Soil inorganic phosphorus fractions and their uptake relationships in calcareous soils. Soil Sci Soc Am J 54:1666-1669

Zohlen A, Tyler G (2004) Soluble inorganic tissue phosphorus and calcicole-calcifuge behaviour of plants. Ann Bot 94:427-432 